\title{
Mining the Royal Jelly Proteins: Combinatorial Hexapeptide Ligand Library Significantly Improves the MS-Based Proteomic Identification in Complex Biological Samples
}

\author{
Eliza Matuszewska ${ }^{1}{ }^{(}$, Joanna Matysiak ${ }^{2}{ }^{(0}$, Grzegorz Rosiński $^{3}$, Elżbieta Kędzia ${ }^{4}$, Weronika Ząbek ${ }^{5}{ }^{(}$, \\ Jarosław Zawadziński ${ }^{6}$ and Jan Matysiak ${ }^{1, * \mathbb{D}}$
}

1 Department of Inorganic and Analytical Chemistry, Poznan University of Medical Sciences, Grunwaldzka 6 Street, 60-780 Poznań, Poland; eliza.matuszewska@ump.edu.pl

2 Faculty of Health Sciences, Calisia University, Kaszubska 13 Street, 62-800 Kalisz, Poland; jkamatysiak@gmail.com

3 Department of Animal Physiology and Development, Faculty of Biology, Adam Mickiewicz University in Poznan, Uniwersytetu Poznańskiego 6 Street, 61-614 Poznań, Poland; rosin@amu.edu.pl

4 Department of Innovative Biomaterials and Nanotechnologies, Institute of Natural Fibres and Medicinal Plants-National Research Institute, Wojska Polskiego 71B Street, 60-630 Poznań, Poland; elzbieta.kedzia@iwnirz.pl

5 Department of Pediatric Gastroenterology and Metabolic Diseases, Poznan University of Medical Sciences, Szpitalna 27/33 Street, 60-572 Poznań, Poland; weronikazabek@wp.eu

check for

updates

Citation: Matuszewska, E.; Matysiak J.; Rosiński, G.; Kẹdzia, E.; Ząbek, W.; Zawadziński, J.; Matysiak, J. Mining the Royal Jelly Proteins:

Combinatorial Hexapeptide Ligand

Library Significantly Improves the

MS-Based Proteomic Identification in Complex Biological Samples.

Molecules 2021, 26, 2762. https://

doi.org/10.3390/molecules26092762

Academic Editors: Gavino Sanna and Joselito P. Quirino

Received: 15 March 2021

Accepted: 4 May 2021

Published: 7 May 2021

Publisher's Note: MDPI stays neutral with regard to jurisdictional claims in published maps and institutional affiliations.

Copyright: (c) 2021 by the authors Licensee MDPI, Basel, Switzerland. This article is an open access article distributed under the terms and conditions of the Creative Commons Attribution (CC BY) license (https:// creativecommons.org/licenses/by/ $4.0 /)$.
6 Department of Physiotherapy, Poznan University of Medical Sciences, 28 Czerwca 1956 r. 135/147 Street, 61-545 Poznań, Poland; jaroslaw.zawadzinski@gmail.com

* Correspondence: jmatysiak@ump.edu.pl

Abstract: Royal jelly (RJ) is a complex, creamy secretion produced by the glands of worker bees. Due to its health-promoting properties, it is used by humans as a dietary supplement. However, RJ compounds are not fully characterized yet. Hence, in this research, we aimed to broaden the knowledge of the proteomic composition of fresh RJ. Water extracts of the samples were pre-treated using combinatorial hexapeptide ligand libraries (ProteoMiner ${ }^{\mathrm{TM}}$ kit), trypsin-digested, and analyzed by a nanoLC-MALDI-TOF/TOF MS system. To check the ProteoMiner ${ }^{\mathrm{TM}}$ performance in the MS-based protein identification, we also examined RJ extracts that were not prepared with the ProteoMiner ${ }^{\mathrm{TM}}$ kit. We identified a total of 86 proteins taxonomically classified to Apis spp. (bees). Among them, 74 proteins were detected in RJ extracts pre-treated with ProteoMiner ${ }^{\mathrm{TM}}$ kit, and only 50 proteins were found in extracts non-enriched with this technique. Ten of the identified features were hypothetical proteins whose existence has been predicted, but any experimental evidence proves their in vivo expression. Additionally, we detected four uncharacterized proteins of unknown functions. The results of this research indicate that the ProteoMiner ${ }^{\mathrm{TM}}$ strategy improves proteomic identification in complex biological samples. Broadening the knowledge of RJ composition may contribute to the development of standards and regulations, enhancing the quality of RJ, and consequently, the safety of its supplementation.

Keywords: royal jelly; proteins; ProteoMiner ${ }^{\mathrm{TM}}$; MALDI-TOF-MS; proteomics; beehive product

\section{Introduction}

Bee products are unique, complex mixtures of biologically active compounds produced by honeybees (Apis mellifera). They exhibit strong health-promoting properties, appreciated since ancient times and used for medical purposes. Until now, they are recommended as drugs within the branch of alternative medicine called apitherapy [1]. One of the most sterling bee products, along with honey, bee pollen, and propolis, is royal jelly (RJ). It is a semi-liquid, milky white or yellowish secretion of worker bees' salivary glands. Its sour-bitter-sweet taste (resulting from its acidic $\mathrm{pH}$ ) and characteristic phenolic smell make 
it mostly recognizable among the so-called "superfoods" [2]. The term "superfoods" refers to foods that have beneficial effects on human health due to their rich nutrient content [3], and RJ fits this description well.

Chemically, fresh RJ consists of about $60-70 \%$ water, $11-23 \%$ carbohydrates, 9-18\% proteins, 3-8\% lipids, and small amounts of vitamins, minerals, free amino acids, and other constituents $[2,4,5]$. According to the literature reports, $\mathrm{RJ}$ is nonhomogeneous, displaying high variability between its main components [5-10]. Factors responsible for that variability are the metabolic and physiologic condition of worker bees and larval age [10-12], honeybee strain [13], place of origin, and year and season of the collection [11]. Since the fluctuations in RJ composition may significantly influence its biological activity, standardization, and quality control of RJ and other bee products seem to be an essential issue.

In a beehive, RJ serves as superior nourishment for all bee larvae until the prepupal stage. However, the honeybee queen is fed exclusively with RJ for its lifetime [14]. Since only the queen is able to reproduce, the epigenetic influence of $\mathrm{RJ}$ in the sexual maturation of the female bee larvae is unquestionable. Although it is not thoroughly investigated yet, how RJ provokes the queen's development, monomeric major royal jelly protein 1 (MRJP1; royalactin), belonging to a major royal jelly proteins (MRJP) family, has been suggested to influence the larva differentiation into a bee queen [15]. Nevertheless, the mechanism of RJ's action is probably more complicated, dependent not on the single compound but on the unique molecular blend found exclusively in RJ [16]. Hence, taking into account that RJ is the exceptional food of the bee queen, but it is also used in the treatment and prevention of some diseases, there is an urgent need to characterize the complete RJ composition, including macro- and micro-molecules, along with their biological functions. This will contribute to explaining the effects of royal jelly on the human body and also its beneficial and adverse properties in relation to both humans and animals.

Benefits arising from RJ consumption attract people to include it in their diet. However, the use of not thoroughly tested products poses a risk of side effects, such as inflammatory and allergic reactions, dermatitis, asthma, respiratory stress and bronchospasm, gastrointestinal problems, intestinal bleeding, and even death. Most of the factors responsible for both beneficial and harmful effects caused by RJ intake remain uncharacterized. Hence, taking into account that proteins are mostly accountable for the biological activity of the product, in this research, we aimed to broaden the knowledge of the proteomic composition of fresh RJ.

According to the available literature, several analytical methods have been proposed for the proteomic analysis of RJ. Since MRJPs are easily soluble in water, most of the researchers have extracted proteins contained in RJ using ultrapure water or buffer solutions [17-22]. Hence, in this study, we chose water as an optimal solvent. RJ is a complex product eminently rich in proteins [23]. Therefore, in other studies conducted worldwide, before identification, protein extracts were subjected to tryptic digestion and fractionated, using liquid chromatography or isoelectric fractionation approach. The identification analyses were performed mainly by electrophoretic techniques or mass spectrometry [17-21,24-26]. In this study, we decided to utilize proteolytic digestion, nanoLC (nano-liquid chromatography) and tandem MALDI-TOF/TOF (matrix-assisted laser desorption/ionization - time of flight/time of flight) mass spectrometer.

In the proteomic investigation of natural products such as RJ, a major challenge is analysis of low-abundant proteins. Because there are significant differences in the concentrations of different proteins contained in RJ with a high content of MRJPs fraction, it is important to focus on proper samples preparation for proteomic analyses. However, according to the literature data, any previous study devised an efficient method for subproteome isolation. Therefore, we proposed the ProteoMiner ${ }^{\mathrm{TM}}$ (Bio-Rad, Hercules, CA, USA) kit for proteins purifying and concentration. ProteoMiner ${ }^{\mathrm{TM}}$ uses combinatorial hexapeptide ligand libraries, and it is a protein enrichment strategy allowing capturing low- and very low-abundance proteins. Such prepared RJ protein extracts were analyzed with advanced nanoLC-MALDI-TOF/TOF MS/MS (nano-liquid chromatography-matrix- 
assisted laser desorption/ionization—time of flight/time of flight mass spectrometry/mass spectrometry) technique. To the best of our knowledge, according to the available literature, it is the first attempt to analyse the proteomic fraction of RJ samples using ProteoMiner ${ }^{\mathrm{TM}}$ protein enrichment approach.

\section{Results}

The methodology proposed for the analysis of RJ samples allowed us to identify a total of 86 proteins taxonomically classified to Apis spp. (Table 1). Among them, 50 proteins were detected in "crude" RJ water extracts, which were not pre-treated with ProteoMiner ${ }^{\mathrm{TM}}$ kit, and 74 proteins were found in extracts enriched with this commercial technique (total in all fractions). The numbers of proteins identified in "crude" extracts, extracts pre-treated with ProteoMiner ${ }^{\mathrm{TM}}$, and both in "crude" and ProteoMiner ${ }^{\mathrm{TM}}$ pre-treated extracts are presented in Figure 1.

Table 1. List of proteins identified in royal jelly found in: CRJ-“crude" (non-enriched with ProteoMiner ${ }^{\mathrm{TM}}$ technique) water extracts of royal jelly; F1, F2, F3, F4-separate fractions obtained from ProteoMiner ${ }^{\mathrm{TM}}$ elution with 1 M sodium chloride, 20 mM HEPES, pH 7.4 (F1), 200 mM glycine, pH 2.4 (F2), 60\% ethylene glycol in water (F3), and 33.3\% 2-propanol, $16.7 \%$ acetonitrile (ACN), $0.1 \%$ trifluoroacetic acid (TFA) (F4); MW—-molecular weight; pI-isoelectric point. Fractions, in which proteins were detected, marked with " $x$ ".

\begin{tabular}{|c|c|c|c|c|c|c|c|c|c|}
\hline Accession & Protein Name & Function & MW [kDa] & pI & CRJ & F1 & F2 & F3 & F4 \\
\hline gi | 110749126 & $\begin{array}{l}\text { Predicted: glucose dehydrogenase [acceptor] } \\
\text { isoform } 3 \text { [Apis mellifera] }\end{array}$ & Enzyme & 70.1 & 6.7 & & $\mathrm{x}$ & & & \\
\hline gi| 110751029 & $\begin{array}{l}\text { Predicted: e3 ubiquitin-protein ligase } \\
\text { IAP-3-like [Apis mellifera] }\end{array}$ & Enzyme & 43.2 & 6.4 & & & & & $\mathrm{x}$ \\
\hline gi | 110756431 & $\begin{array}{l}\text { Predicted: hypothetical protein LOC725074 } \\
\text { [Apis mellifera] }\end{array}$ & & 8.3 & 10.2 & $\mathrm{x}$ & & & & \\
\hline gi | 110758964 & Predicted: regucalcin-like [Apis mellifera] & Binding & 10.2 & 9.4 & $\mathrm{x}$ & & & & $\mathrm{x}$ \\
\hline gi | 110763647 & $\begin{array}{l}\text { Predicted: hypothetical protein LOC726323 } \\
\text { [Apis mellifera] }\end{array}$ & & 18.5 & 7.9 & & & & & $\mathrm{x}$ \\
\hline gi| 13184963 & defensin [Apis mellifera] & Defense & 6.3 & 6.5 & & & & & $x$ \\
\hline gi| 166795901 & $\begin{array}{l}\text { apolipophorin-III-like protein precursor } \\
\text { [Apis mellifera] }\end{array}$ & Binding & 21.3 & 5.4 & $\mathrm{x}$ & $\mathrm{x}$ & $\mathrm{x}$ & $\mathrm{x}$ & $x$ \\
\hline gi | 202078658 & defensin $[$ Apis cerana cerana $]$ & Defense & 10.6 & 7.8 & $\mathrm{x}$ & & & & \\
\hline gi | 202078660 & defensin [Apis cerana cerana] & Defense & 10.7 & 7.8 & & & $\mathrm{x}$ & & \\
\hline gi | 254548151 & defensin precursor [Apis cerana] & Defense & 8.7 & 6.4 & $\mathrm{x}$ & $\mathrm{x}$ & $\mathrm{x}$ & $\mathrm{x}$ & $\mathrm{x}$ \\
\hline gi| 254548155 & defensin precursor [Apis mellifera] & Defense & 8.8 & 5.9 & $\mathrm{x}$ & $x$ & $x$ & $\mathrm{x}$ & $\mathrm{x}$ \\
\hline gi | 254910938 & defensin-1 preproprotein [Apis mellifera] & Defense & 10.7 & 6.4 & & & $\mathrm{x}$ & & \\
\hline gi | 258678306 & MRJP9 [Apis cerana] & $\begin{array}{l}\text { Honeybee nutrition and } \\
\text { development }\end{array}$ & 19.4 & 9.2 & & & $\mathrm{x}$ & & \\
\hline gi | 258678310 & MRJP5 [Apis dorsata] & $\begin{array}{c}\text { Honeybee nutrition and } \\
\text { development }\end{array}$ & 21.3 & 4.7 & $\mathrm{x}$ & & & & \\
\hline gi | 258678314 & MRJP6 [Apis florea] & $\begin{array}{c}\text { Honeybee nutrition and } \\
\text { development }\end{array}$ & 21.5 & 4.4 & & $\mathrm{x}$ & $\mathrm{x}$ & & \\
\hline gi | 258678316 & MRJP9 [Apis florea] & $\begin{array}{c}\text { Honeybee nutrition and } \\
\text { development }\end{array}$ & 21.0 & 5.5 & $\mathrm{x}$ & $\mathrm{x}$ & $\mathrm{x}$ & $\mathrm{x}$ & $\mathrm{x}$ \\
\hline gi | 283105164 & alpha-glucosidase III [Apis dorsata] & Enzyme & 65.5 & 5.0 & $\mathrm{x}$ & & & & $\mathrm{x}$ \\
\hline gi | 284182838 & major royal jelly protein 4 [Apis mellifera] & $\begin{array}{l}\text { Honeybee nutrition and } \\
\text { development }\end{array}$ & 53.0 & 5.9 & $\mathrm{x}$ & $\mathrm{x}$ & $\mathrm{x}$ & $\mathrm{x}$ & \\
\hline gi | 284812514 & MRJP5 [Apis mellifera] & $\begin{array}{c}\text { Honeybee nutrition and } \\
\text { development }\end{array}$ & 70.1 & 6.1 & $\mathrm{x}$ & $\mathrm{x}$ & $\mathrm{x}$ & $\mathrm{x}$ & $\mathrm{x}$ \\
\hline gi | 288872651 & major royal jelly protein [Apis mellifera] & $\begin{array}{c}\text { Honeybee nutrition and } \\
\text { development }\end{array}$ & 61.6 & 6.7 & $\mathrm{x}$ & $\mathrm{x}$ & $\mathrm{x}$ & $\mathrm{x}$ & $\mathrm{x}$ \\
\hline gi | 28972896 & $\begin{array}{c}\text { major royal jelly protein-like protein } \\
\text { [Apis dorsata] }\end{array}$ & $\begin{array}{c}\text { Honeybee nutrition and } \\
\text { development }\end{array}$ & 9.2 & 9.8 & $\mathrm{x}$ & $\mathrm{x}$ & $\mathrm{x}$ & $\mathrm{x}$ & $\mathrm{x}$ \\
\hline gi | 328775853 & $\begin{array}{l}\text { Predicted: DNA replication licensing factor } \\
\text { MCM4-like [Apis mellifera] }\end{array}$ & Binding & 80.7 & 6.9 & & $\mathrm{x}$ & & & \\
\hline gi | 328777366 & $\begin{array}{l}\text { Predicted: hypothetical protein LOC100577348 } \\
\text { [Apis mellifera] }\end{array}$ & & 61.1 & 10.5 & & & $\mathrm{x}$ & & \\
\hline gi | 328779534 & $\begin{array}{l}\text { Predicted: hypothetical protein LOC552041 } \\
\text { [Apis mellifera] }\end{array}$ & & 79.3 & 4.2 & & & & & $\mathrm{x}$ \\
\hline gi | 328782858 & $\begin{array}{l}\text { Predicted: hypothetical protein LOC410515 } \\
\text { [Apis mellifera] }\end{array}$ & & 190.2 & 6.4 & $\mathrm{x}$ & & & & \\
\hline
\end{tabular}


Table 1. Cont.

\begin{tabular}{|c|c|c|c|c|c|c|c|c|c|}
\hline Accession & Protein Name & Function & MW [kDa] & $\mathrm{pI}$ & CRJ & F1 & F2 & F3 & F4 \\
\hline gi | 328783362 & $\begin{array}{c}\text { Predicted: hypothetical protein LOC725249 } \\
\text { [Apis mellifera] }\end{array}$ & & 6.3 & 4.9 & $\mathrm{x}$ & & & & \\
\hline gi|328783471 & $\begin{array}{c}\text { Predicted: hypothetical protein LOC725114 } \\
\text { isoform } 1 \text { [Apis mellifera] }\end{array}$ & & 10.1 & 5.7 & $x$ & & & & \\
\hline gi | 328784821 & $\begin{array}{l}\text { Predicted: hypothetical protein LOC100577210 } \\
\text { [Apis mellifera] }\end{array}$ & & 11.6 & 5.9 & $\mathrm{x}$ & $\mathrm{x}$ & & $\mathrm{x}$ & $\mathrm{x}$ \\
\hline gi | 328789019 & Predicted: protein SERAC1-like [Apis mellifera] & Remodeling & 87.5 & 9.2 & & $x$ & & & \\
\hline gi | 328790726 & $\begin{array}{l}\text { Predicted: venom acid phosphatase } \\
\text { Acph-1-like [Apis mellifera] }\end{array}$ & Enzyme & 42.6 & 8.5 & & & & & $\mathrm{x}$ \\
\hline gi | 328792767 & $\begin{array}{l}\text { Predicted: hypothetical protein LOC724993 } \\
\text { [Apis mellifera] }\end{array}$ & & 43.8 & 5.4 & & & $\mathrm{x}$ & & \\
\hline gi | 328793775 & $\begin{array}{c}\text { Predicted: s-adenosylmethionine } \\
\text { decarboxylase proenzyme-like, partial } \\
\text { [Apis mellifera] }\end{array}$ & Enzyme & 32.1 & 4.6 & $x$ & & & & \\
\hline gi | 328794347 & $\begin{array}{c}\text { Predicted: major royal jelly protein 3-like, } \\
\text { partial [Apis mellifera] }\end{array}$ & $\begin{array}{l}\text { Honeybee nutrition and } \\
\text { development }\end{array}$ & 42.7 & 6.5 & $\mathrm{x}$ & & $\mathrm{x}$ & & \\
\hline gi|33358394 & $\begin{array}{c}\text { major royal jelly protein MRJP1 [Apis cerana } \\
\text { cerana] }\end{array}$ & $\begin{array}{c}\text { Honeybee nutrition and } \\
\text { development }\end{array}$ & 49.0 & 5.4 & $\mathrm{x}$ & $x$ & $\mathrm{x}$ & $\mathrm{x}$ & $\mathrm{x}$ \\
\hline gi | 380011960 & $\begin{array}{c}\text { Predicted: slit homolog } 2 \text { protein-like } \\
\text { [Apis florea] }\end{array}$ & Binding & 155.3 & 6.0 & & $\mathrm{x}$ & & & \\
\hline gi | 380012917 & $\begin{array}{l}\text { Predicted: uncharacterized protein } \\
\text { LOC100870850 [Apis florea] }\end{array}$ & & 18.9 & 7.2 & & & & $\mathrm{x}$ & \\
\hline gi|380013532 & $\begin{array}{l}\text { Predicted: Low Quality Protein: clathrin heavy } \\
\text { chain-like [Apis florea] }\end{array}$ & Binding & 187.7 & 5.6 & & & $\mathrm{x}$ & & \\
\hline gi | 380016522 & $\begin{array}{l}\text { Predicted: probable bifunctional } \\
\text { methylenetetrahydrofolate } \\
\text { dehydrogenase/cyclohydrolase 2-like } \\
\text { [Apis florea] }\end{array}$ & Enzyme & 39.9 & 9.6 & & $\mathrm{x}$ & & & \\
\hline gi | 380017034 & Predicted: glucosylceramidase-like [Apis florea] & Enzyme & 60.8 & 5.5 & & & & $\mathrm{x}$ & $\mathrm{x}$ \\
\hline gi | 380019073 & $\begin{array}{c}\text { Predicted: lysozyme 1-like isoform } 2 \\
\text { [Apis florea] }\end{array}$ & Enzyme & 13.8 & 4.6 & $\mathrm{x}$ & & & $x$ & $x$ \\
\hline gi | 380020436 & Predicted: regucalcin-like [Apis florea] & Binding & 37.7 & 5.3 & $x$ & $x$ & & $x$ & $x$ \\
\hline gi | 380022658 & $\begin{array}{c}\text { Predicted: major royal jelly protein 3-like } \\
\text { [Apis florea] }\end{array}$ & $\begin{array}{c}\text { Honeybee nutrition and } \\
\text { development }\end{array}$ & 62.7 & 7.8 & $\mathrm{x}$ & $x$ & & & \\
\hline gi I 380022660 & $\begin{array}{c}\text { Predicted: major royal jelly protein } 4 \text {-like } \\
\text { [Apis florea] }\end{array}$ & $\begin{array}{c}\text { Honeybee nutrition and } \\
\text { development }\end{array}$ & 56.1 & 6.1 & & & & $x$ & \\
\hline gi | 380022665 & $\begin{array}{c}\text { Predicted: major royal jelly protein } 1 \text {-like } \\
\text { [Apis florea] }\end{array}$ & $\begin{array}{c}\text { Honeybee nutrition and } \\
\text { development }\end{array}$ & 43.9 & 5.3 & $\mathrm{x}$ & $\mathrm{x}$ & $\mathrm{x}$ & $\mathrm{x}$ & $\mathrm{x}$ \\
\hline gi | 380022667 & $\begin{array}{c}\text { Predicted: major royal jelly protein 2-like } \\
\text { [Apis florea] }\end{array}$ & $\begin{array}{c}\text { Honeybee nutrition and } \\
\text { development }\end{array}$ & 49.1 & 5.7 & $\mathrm{x}$ & $\mathrm{x}$ & & & \\
\hline gi|380022669 & $\begin{array}{c}\text { Predicted: major royal jelly protein 2-like } \\
\text { [Apis florea] }\end{array}$ & $\begin{array}{c}\text { Honeybee nutrition and } \\
\text { development }\end{array}$ & 49.3 & 6.0 & $x$ & $\mathrm{x}$ & $x$ & $x$ & $\mathrm{x}$ \\
\hline gi|380022673 & $\begin{array}{c}\text { Predicted: major royal jelly protein 5-like } \\
\text { [Apis florea] }\end{array}$ & $\begin{array}{c}\text { Honeybee nutrition and } \\
\text { development }\end{array}$ & 34.2 & 4.7 & & & $x$ & & \\
\hline gi|380022681 & $\begin{array}{c}\text { Predicted: major royal jelly protein } 5 \text {-like } \\
\text { isoform } 2[\text { Apis florea }]\end{array}$ & $\begin{array}{c}\text { Honeybee nutrition and } \\
\text { development }\end{array}$ & 47.5 & 9.2 & & $x$ & & & \\
\hline gi | 380023404 & $\begin{array}{l}\text { Predicted: uncharacterized protein } \\
\text { LOC100869599 [Apis florea] }\end{array}$ & & 18.7 & 9.5 & $\mathrm{x}$ & & & $\mathrm{x}$ & $\mathrm{x}$ \\
\hline gi|380024584 & $\begin{array}{c}\text { Predicted: chymotrypsin inhibitor-like } \\
\text { [Apis florea] }\end{array}$ & Enzyme inhibitor & 5.6 & 10.0 & $x$ & & & & \\
\hline gi | 380024588 & $\begin{array}{c}\text { Predicted: chymotrypsin inhibitor-like } \\
\text { [Apis florea] }\end{array}$ & Enzyme inhibitor & 8.0 & 5.0 & $\mathrm{x}$ & & & & \\
\hline gi | 380025248 & $\begin{array}{c}\text { Predicted: alkylated DNA repair protein alkB } \\
\text { homolog 8-like [Apis florea] }\end{array}$ & Enzyme & 68.2 & 9.3 & $\mathrm{x}$ & $\mathrm{x}$ & & & \\
\hline gi | 380025500 & $\begin{array}{c}\text { Predicted: venom acid phosphatase } \\
\text { Acph-1-like [Apis florea] }\end{array}$ & Enzyme & 39.9 & 4.9 & & & & & $\mathrm{x}$ \\
\hline gi | 380025661 & $\begin{array}{l}\text { Predicted: glucose dehydrogenase } \\
\text { [acceptor]-like [Apis florea] }\end{array}$ & Enzyme & 67.9 & 6.4 & $\mathrm{x}$ & $\mathrm{x}$ & & $\mathrm{x}$ & $\mathrm{x}$ \\
\hline gi | 380026601 & $\begin{array}{l}\text { Predicted: uncharacterized protein } \\
\text { LOC100863702 [Apis florea] }\end{array}$ & & 9.9 & 5.0 & & & & $\mathrm{x}$ & $\mathrm{x}$ \\
\hline gil 380027252 & $\begin{array}{l}\text { Predicted: uncharacterized protein } \\
\text { LOC100864410 [Apis florea] }\end{array}$ & & 33.4 & 9.7 & & & $\mathrm{x}$ & & \\
\hline gi | 380028593 & $\begin{array}{l}\text { Predicted: Low Quality Protein: } \\
\text { delta-1-pyrroline-5-carboxylate } \\
\text { synthase-like [Apis florea] }\end{array}$ & Enzyme & 84.9 & 9.1 & & & $x$ & & \\
\hline
\end{tabular}


Table 1. Cont.

\begin{tabular}{|c|c|c|c|c|c|c|c|c|c|}
\hline Accession & Protein Name & Function & MW [kDa] & $\mathrm{pI}$ & CRJ & F1 & F2 & F3 & F4 \\
\hline gi | 40218299 & $\begin{array}{c}\text { major royal jelly protein MRJP5 [Apis cerana } \\
\text { cerana] }\end{array}$ & $\begin{array}{c}\text { Honeybee nutrition and } \\
\text { development }\end{array}$ & 70.5 & 8.8 & & $\mathrm{x}$ & & & \\
\hline gi | 40218301 & $\begin{array}{c}\text { major royal jelly protein MRJP2 [Apis cerana } \\
\text { cerana] }\end{array}$ & $\begin{array}{c}\text { Honeybee nutrition and } \\
\text { development }\end{array}$ & 53.0 & 9.1 & $\mathrm{x}$ & & $\mathrm{x}$ & & $\mathrm{x}$ \\
\hline gi | 40557703 & $\begin{array}{l}\text { major royal jelly protein MRJP1 precursor } \\
\text { [Apis cerana] }\end{array}$ & $\begin{array}{l}\text { Honeybee nutrition and } \\
\text { development }\end{array}$ & 48.9 & 5.4 & $\mathrm{x}$ & $\mathrm{x}$ & $\mathrm{x}$ & $\mathrm{x}$ & $\mathrm{x}$ \\
\hline gi | 40557705 & $\begin{array}{c}\text { major royal jelly protein MRJP2 precursor } \\
\text { [Apis cerana] }\end{array}$ & $\begin{array}{l}\text { Honeybee nutrition and } \\
\text { development }\end{array}$ & 52.5 & 8.9 & $\mathrm{x}$ & $\mathrm{x}$ & $\mathrm{x}$ & $\mathrm{x}$ & $x$ \\
\hline gi | 42601246 & $\begin{array}{c}\text { major royal jelly protein MRJP5 precursor } \\
\text { [Apis cerana] }\end{array}$ & $\begin{array}{c}\text { Honeybee nutrition and } \\
\text { development }\end{array}$ & 68.2 & 9.3 & & $\mathrm{x}$ & & & $\mathrm{x}$ \\
\hline gi | 46358503 & major royal jelly protein 2 [Apis cerana] & $\begin{array}{c}\text { Honeybee nutrition and } \\
\text { development }\end{array}$ & 52.4 & 8.9 & $\mathrm{x}$ & $\mathrm{x}$ & $\mathrm{x}$ & $\mathrm{x}$ & $\mathrm{x}$ \\
\hline gi | 48094573 & $\begin{array}{l}\text { Predicted: hypothetical protein LOC408608 } \\
\text { [Apis mellifera] }\end{array}$ & & 19.4 & 7.5 & & & & $\mathrm{x}$ & $\mathrm{x}$ \\
\hline gi | 48101366 & $\begin{array}{c}\text { Predicted: venom serine protease } 34 \\
\text { [Apis mellifera] }\end{array}$ & Enzyme & 44.6 & 5.9 & & & & $\mathrm{x}$ & \\
\hline gi | 562090 & defensin precursor [Apis mellifera] & Defense & 10.7 & 6.4 & & & $\mathrm{x}$ & $\mathrm{x}$ & \\
\hline gi | 56422035 & $\begin{array}{l}\text { major royal jelly protein } 3 \text { [Apis mellifera } \\
\text { carnica] }\end{array}$ & $\begin{array}{l}\text { Honeybee nutrition and } \\
\text { development }\end{array}$ & 65.7 & 7.1 & $\mathrm{x}$ & $\mathrm{x}$ & $\mathrm{x}$ & $\mathrm{x}$ & $\mathrm{x}$ \\
\hline gi | 56422037 & major royal jelly protein 3 [Apis cerana] & $\begin{array}{c}\text { Honeybee nutrition and } \\
\text { development }\end{array}$ & 69.2 & 9.3 & $\mathrm{x}$ & $\mathrm{x}$ & & $\mathrm{x}$ & \\
\hline gi | 56422041 & major royal jelly protein 3 [Apis florea] & $\begin{array}{c}\text { Honeybee nutrition and } \\
\text { development }\end{array}$ & 59.3 & 6.4 & $\mathrm{x}$ & & & & \\
\hline gi | 57546160 & major rojal jelly protein 7 [Apis cerana] & $\begin{array}{l}\text { Honeybee nutrition and } \\
\text { development }\end{array}$ & 24.9 & 5.5 & $\mathrm{x}$ & $\mathrm{x}$ & $\mathrm{x}$ & $x$ & $x$ \\
\hline gi | 58585090 & glucose oxidase [Apis mellifera] & Enzyme & 67.9 & 6.5 & & & & $\mathrm{x}$ & $\mathrm{x}$ \\
\hline gi | 58585098 & $\begin{array}{c}\text { major royal jelly protein } 1 \text { precursor } \\
\text { [Apis mellifera] }\end{array}$ & $\begin{array}{l}\text { Honeybee nutrition and } \\
\text { development }\end{array}$ & 48.9 & 5.0 & $\mathrm{x}$ & $\mathrm{x}$ & $\mathrm{x}$ & $x$ & $x$ \\
\hline gi | 58585108 & $\begin{array}{c}\text { major royal jelly protein } 2 \text { precursor } \\
\text { [Apis mellifera] }\end{array}$ & $\begin{array}{c}\text { Honeybee nutrition and } \\
\text { development }\end{array}$ & 51.0 & 7.0 & $\mathrm{x}$ & $\mathrm{x}$ & $\mathrm{x}$ & $\mathrm{x}$ & $\mathrm{x}$ \\
\hline gi | 58585138 & $\begin{array}{c}\text { major royal jelly protein } 5 \text { precursor } \\
\text { [Apis mellifera] }\end{array}$ & $\begin{array}{c}\text { Honeybee nutrition and } \\
\text { development }\end{array}$ & 70.2 & 5.9 & $\mathrm{x}$ & & & & \\
\hline gi | 58585142 & $\begin{array}{c}\text { major royal jelly protein } 3 \text { precursor } \\
\text { [Apis mellifera] }\end{array}$ & $\begin{array}{c}\text { Honeybee nutrition and } \\
\text { development }\end{array}$ & 61.6 & 6.5 & $\mathrm{x}$ & & $\mathrm{x}$ & & $\mathrm{x}$ \\
\hline gi | 58585164 & alpha-glucosidase precursor [Apis mellifera] & Enzyme & 65.5 & 4.9 & & & & & $\mathrm{x}$ \\
\hline gi | 58585170 & $\begin{array}{c}\text { major royal jelly protein } 4 \text { precursor } \\
{[\text { Apis mellifera }]}\end{array}$ & $\begin{array}{l}\text { Honeybee nutrition and } \\
\text { development }\end{array}$ & 52.9 & 5.9 & $\mathrm{x}$ & $\mathrm{x}$ & $\mathrm{x}$ & $\mathrm{x}$ & $\mathrm{x}$ \\
\hline gi | 58585188 & $\begin{array}{c}\text { major royal jelly protein } 6 \text { precursor } \\
\text { [Apis mellifera] }\end{array}$ & $\begin{array}{c}\text { Honeybee nutrition and } \\
\text { development } \\
\text { Venom }\end{array}$ & 49.8 & 5.9 & $\mathrm{x}$ & $\mathrm{x}$ & $\mathrm{x}$ & $\mathrm{x}$ & $\mathrm{x}$ \\
\hline gil 60115688 & icarapin-like precursor [Apis mellifera] & $\begin{array}{l}\text { carbohydrate-rich } \\
\text { protein }\end{array}$ & 24.8 & 4.4 & $\mathrm{x}$ & $x$ & & $\mathrm{x}$ & $x$ \\
\hline gi | 62198227 & $\begin{array}{c}\text { major royal jelly protein } 7 \text { precursor } \\
\text { [Apis mellifera] }\end{array}$ & $\begin{array}{c}\text { Honeybee nutrition and } \\
\text { development }\end{array}$ & 50.5 & 4.8 & $\mathrm{x}$ & $\mathrm{x}$ & $\mathrm{x}$ & $\mathrm{x}$ & $\mathrm{x}$ \\
\hline gi | 66504790 & $\begin{array}{l}\text { Predicted: integrator complex subunit 7-like } \\
\text { isoform } 1 \text { [Apis mellifera] }\end{array}$ & snRNA processing & 105.9 & 9.5 & $\mathrm{x}$ & & & & \\
\hline gi | 66511554 & $\begin{array}{c}\text { Predicted: glucosylceramidase-like isoform } 1 \\
\text { [Apis mellifera] }\end{array}$ & Enzyme & 59.3 & 5.2 & $\mathrm{x}$ & $\mathrm{x}$ & $\mathrm{x}$ & $\mathrm{x}$ & $\mathrm{x}$ \\
\hline gi | 66564326 & $\begin{array}{l}\text { Predicted: plasma glutamate } \\
\text { carboxypeptidase-like isoform } 1 \text { [Apis mellifera] }\end{array}$ & Enzyme & 52.9 & 5.1 & & & & & $\mathrm{x}$ \\
\hline gil 66565246 & Predicted: lysozyme isoform 1 [Apis mellifera] & Enzyme & 17.1 & 4.6 & & & & $x$ & $x$ \\
\hline gi | 94471624 & icarapin variant 2 precursor [Apis mellifera] & $\begin{array}{l}\text { carbohydrate-rich } \\
\text { protein }\end{array}$ & 19.6 & 4.2 & & $\mathrm{x}$ & & & \\
\hline
\end{tabular}




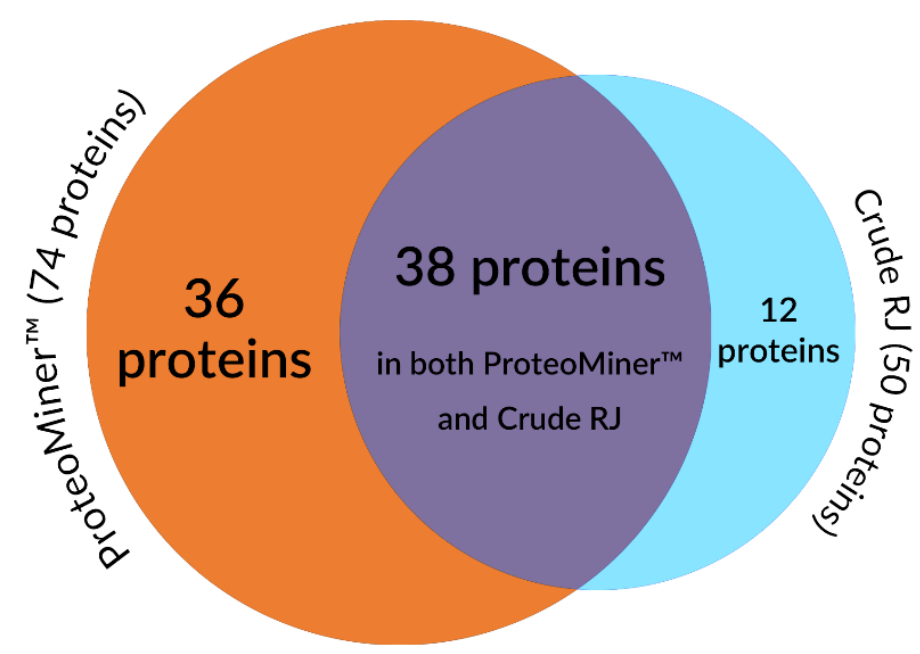

Figure 1. The number of proteins identified in unpurified samples, samples pre-treated with ProteoMiner ${ }^{\mathrm{TM}}$, and both in unpurified and purified samples.

In total, 35 proteins, accounting for $41 \%$ of all proteins identified in this study, belonged to the MRJPs family, responsible for honeybee nutrition and development (Figure 2A). Among them, fragments of MRJP1-MRJP7 and MRJP9 have been detected. The next important functional class of proteins were enzymes (20 proteins; $23 \%$ of all the identified proteins), with glucose dehydrogenase, alpha-glucosidase, venom acid phosphatase, lysozyme, and chymotrypsin inhibitor, among others. Into the most abundant protein classes, we also ranked defensins (7 proteins; representing $8 \%$ of all identified proteins), and binding proteins (6 proteins, accounting for $7 \%$ of all identified proteins), including regucalcin-like proteins. Additionally, four of all 86 proteins $(5 \%)$ were classified into three other functional groups: remodeling proteins, snRNA processing proteins, and venom carbohydrate-rich proteins.

Moreover, ten identified proteins (11\% of all identified proteins) were hypothetical proteins whose existence has been predicted, but there is not any experimental evidence proving their in vivo expression. Additionally, four uncharacterized proteins (5\%) of unknown functions have been detected.

Proteins identified separately in extracts not pre-treated with ProteoMiner ${ }^{\mathrm{TM}}$ enrichment technology were mainly MRJP (28 proteins out of 50 , which represents $56 \%$ of proteins identified only in non-pretreated samples). The next functional classes of proteins included enzymes ( 6 identified proteins; $12 \%$ ), defensins ( 3 proteins; $6 \%$ ), binding proteins ( 3 proteins; $6 \%$ ), and others ( 4 proteins; $8 \%$ ). In these not-enriched samples, five hypothetical proteins (accounting for $10 \%$ of proteins identified in non-enriched samples) and one uncharacterized protein $(2 \%)$ have been detected (Figure $2 \mathrm{~B})$.

Considering only extracts pre-treated with ProteoMiner ${ }^{\mathrm{TM}} \mathrm{kit}$, the protein functional class distribution was comparable to overall results obtained from all compiled samples. MRJP (32 fragments) constituted $43 \%$ of all proteins identified in ProteoMiner ${ }^{\mathrm{TM}}$ fractions. Besides, the most numerous classes were enzymes (17 proteins; $23 \%$ of proteins identified only in ProteoMiner ${ }^{\mathrm{TM}}$ pre-treated samples), followed by defensins (6 proteins; $8 \%$ ), binding proteins (6 proteins; $8 \%$ ) and others (3 proteins; $4 \%$ ). In those enriched samples, we also identified 6 ( $8 \%$ of all proteins identified in pre-treated fractions) hypothetical proteins and $4(6 \%)$ uncharacterized proteins (Figure 2C). 


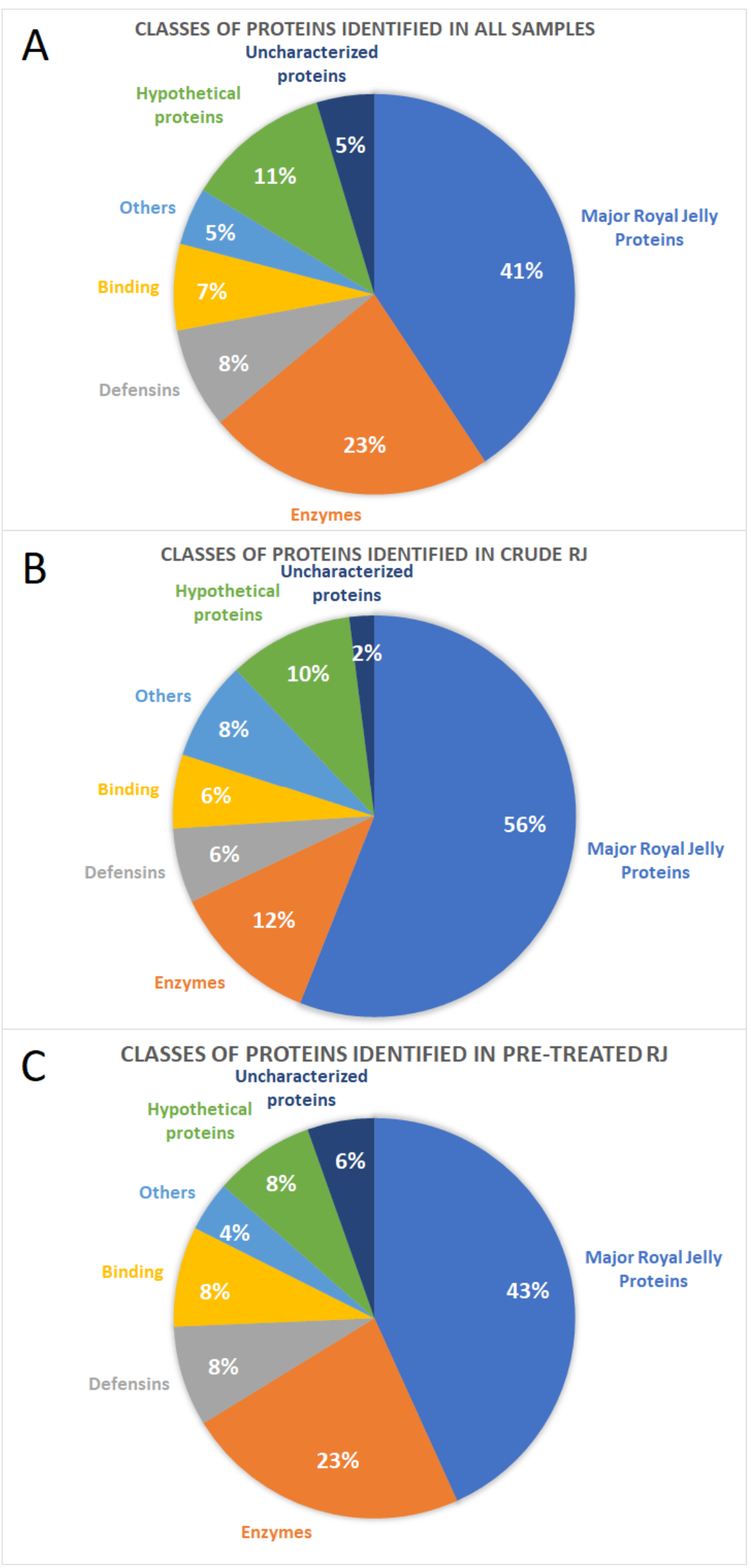

Figure 2. Classes of proteins identified (A) in total in all RJ "crude" and pre-treated; (B) only in crude (non-ProteoMiner ${ }^{\mathrm{TM}}$ pre-treated) RJ samples; (C) only in ProteoMiner ${ }^{\mathrm{TM}}$ pre-treated RJ samples. 
Application of the ProteoMiner ${ }^{\mathrm{TM}}$ technique resulted in expanded identification of proteins that belonged to almost all functional groups. Within the MRJPs group, 9 out of $35(25.7 \%)$ MRJPs identified in total in this study were detected only in ProteoMiner ${ }^{\mathrm{TM}}$ fractions. Moreover, 8 out of 19 (42.1\%) enzymes identified in total were only detected in pre-treated samples. Regarding defensins, as many as 4 additional proteins belonging to this functional group were identified through the use of ProteoMiner ${ }^{\mathrm{TM}}$, whereas only three defensins were identified in the unpurified samples (meaning that $57.1 \%$ of all identified defensins were detected using the ProteoMiner ${ }^{\mathrm{TM}}$ technique). Similarly, out of 6 identified in total binding proteins, 3 of them $(50 \%)$ were detected only in ProteoMiner ${ }^{\mathrm{TM}}$ fractions. These results clearly indicate that the ProteoMiner ${ }^{\mathrm{TM}}$ strategy significantly improves proteomic identification in complex biological samples, increasing the number of some identified functional proteins even more than twice.

Moreover, compared to "crude" extracts, application of the ProteoMiner ${ }^{\mathrm{TM}}$ kit enabled the detection of 5 more hypothetical proteins (out of 10 hypothetical proteins identified in total in this study) and 3 more uncharacterized proteins (out of 4 uncharacterized proteins identified in total in this study). These improvements in identification rate are especially beneficial when trying to find new proteomic features in bio-matrices represented by RJ.

\section{Discussion}

The goal of this study was to characterize the protein-peptide composition of fresh RJ using advanced nanoLC-MALDI-TOF/TOF MS/MS (nano-liquid chromatographymatrix-assisted laser desorption/ionization-time of flight mass spectrometry/mass spectrometry) technique. Despite its many unquestionable advantages, including versatility, ease of use, cost-effectiveness, and possibility to detect biomolecules in extremely low concentrations (even close to sub-femtomoles), the MALDI-TOF MS technique also has some limitations [27]. One of the most challenging issues is the detection of low-abundance proteins and peptides in very complex biological matrices. The presence of high concentration proteins and also other constituents, like lipids and salts, prevent direct analysis of all molecules contained in the sample [28]. Thus, proteins and peptides in low concentration ranges usually remain undetected. To deal with this problem, before MS analyses, biological samples must be purified, and their complexity and dynamic range need to be reduced. In this study, we applied a novel strategy based on a combinatorial hexapeptide ligand library (ProteoMiner ${ }^{\mathrm{TM}}$ ). ProteoMiner ${ }^{\mathrm{TM}}$ technique, by binding proteins to hexapeptides (through protein affinity interactions), resulted in reducing high-abundance proteins and enriching low-abundance proteins in RJ samples [29-31]. In this research, using the ProteoMiner ${ }^{\mathrm{TM}}$ technique significantly improved the number of identified proteins, from 50 in non-enriched RJ water extracts to 74 in ProteoMiner ${ }^{\mathrm{TM}}$ pre-treated extracts.

Application of the proposed methodology resulted in the identification of a total number of 86 proteins (from all samples and ProteoMiner ${ }^{\mathrm{TM}}$ fractions) taxonomically restricted to Apis spp. (Apis mellifera, Apis cerana, Apis dorsata, and Apis florea). As expected on the basis of available literature, the major royal jelly proteins family constituted the largest group. We identified 35 MRJPs or their precursors, which stands for $41 \%$ of the number of all identified proteins. Our results reflect previous independent proteomic studies, which reported that MRJPs account for up to $82-90 \%(w / w)$ of all proteins found in RJ [32-34]. It is also worth noting that in our study of only crude RJ, the percentage of MRJPs in relation to all identified proteins was as high as $56 \%$. These results prove the utility of the ProteoMiner ${ }^{\mathrm{TM}}$ enrichment technique in enhancing the protein identification ability by MS approaches.

MRJPs are a family of nine proteins, of which MRJP1, called apalbumin or royalactin, is the most abundant and also the first MRJP to be identified in 1992 [35]. It has been suggested that MRJPs have mainly nutritional and developmental functions. Moreover, MRJP1 has been reported to exhibit antibacterial and antiproliferative activity [14,36]. Interestingly, the effect of MRJPs and whole RJ on honeybee queen development is not only due to the nutritional properties. MRJP1, along with protein named apisimin, by specific 
complex formation, provide the optimal RJ viscosity. The viscosity is crucial for holding queen larvae on the surface of the comb cells, which are orientated vertically and open downwards [37,38]. The formation of MRJ1-apisimin polymer is strongly $\mathrm{pH}$-dependent. Long structures are formed at $\mathrm{pH}$ about 4.0, measured in fresh RJ [37,39]. The specific acidity is sustained by the fatty acids content produced in the bees' mandibular glands.

The second most-abundant functional group of RJ-identified proteins in this study was enzymes. This group includes some important enzymes crucial for carbohydrate metabolisms, like glucose dehydrogenase, alpha-glucosidase and glucose oxidase. Those enzymes are suggested to play an essential role in facilitating the larvae's digestion of sugars, which are found in RJ in large quantities [19]. The next relevant enzyme identified in our study was lysozyme isoform 1 and 2. Lysozyme is a protein commonly found in animals. It is a natural component of various secretions such as tears, saliva, mucus and milk. Lysozyme exhibits a strong antimicrobial activity, which in beehive prevents bacterial infection and disease $[40,41]$. Furthermore, because of their human benefits, the antibacterial activities of RJ are worthy of notice. These properties were reported as far back as 1939 [42]. According to the literature, besides the lysozyme, a $5.5 \mathrm{kDa}$ defensin peptide named royalisin, and 10-hydroxy-2-decenoic acid (10-HDA) are mainly responsible for the antibacterial activity of RJ [43-45]. Antimicrobial properties, along with anti-inflammatory, immunomodulatory, antioxidant, moisturising, toning, and anti-ageing activities, make $\mathrm{RJ}$ a perfect dermatological product. Hence, $\mathrm{RJ}$ is used for treating various skin lesions and wounds [46,47]. Antibacterial defensins, including royalisin preproprotein (named defensin-1 preproprotein), were also identified in this study.

However, among the enzymes included in RJ, we found venom acid phosphatase Acph-1-like and venom serine protease 34. These proteins, along with MRJP8, MRJP9 and icarapin variant 2 precursor (also found in this study), are classified as bee venom allergens (based on Allergen Nomenclature Database, www.allergen.org, accessed on 8 March 2021). Allergens are responsible for the occurrence of allergic reactions in humans and animals after exposition to bee products [48-50]. The highest risk of an allergic reaction, both local or systemic, is associated with exposure to Hymenoptera venom, especially after the insect sting. Since allergens are present also in other bee products, like RJ (what was proven in this study), bee products should be consumed with caution and in moderation.

According to literature data, allergy to royal jelly is most common IgE-mediated, but contact allergic reactions (contact dermatitis) are also possible. IgE allergic reactions to royal jelly cause symptoms such as urticaria, angioedema, eczema, allergy rhinitis, conjunctivitis, bronchospasm or even anaphylactic shock [51-53]. Patients with bronchial asthma and atopic dermatitis are particularly predisposed to severe reactions to RJ. Even $17 \%$ adult patient with asthma [54] and one third of patient with atopic dermatitis [55] have specific IgE to RJ. Reported cases of allergy to royal jelly concern both people who have consumed this product for the first time or after long use. Allergy reaction to RJ after the first use is possible because of cross-reactivity between RJ and other allergens. Cross-reactions between RJ and bee venom can be associated with proteins found in our study - venom acid phosphatase Acph-1-like, venom serine protease 34, MRJP8, MRJP9 and icarapin variant 2 precursor. Moreover, cross-reactions are also possible with very typical allergens like house dust mite (Dermatophagoides farinae, Dermatophagoides pteronyssinus), German cockroach or crab [55]. In conclusion, RJ can cause an allergic reaction because it contains allergenic proteins and, further, because of cross-reactions with typical allergens. Patients with venom allergy, asthma, atopic dermatitis, and allergic rhinitis should be careful before consuming RJ.

Additionally, to minimalize the risk of dangerous adverse effects, bee products should be thoroughly tested for allergens, both qualitatively and quantitatively. However, despite its undeniable beneficial pro-health properties, the use of RJ in people with local and/or systemic Hymenoptera venom allergic reactions should be avoided.

Although in this study we focused mainly on nutritive MRJPs, and enzymes, defensins, and allergens, we also identified other functional groups of proteins included binding 
proteins, chymotrypsin inhibitors, protein SERAC1-like, and integrator complex subunit 7-like isoform 1 . Those proteins show mainly regulatory activities.

The most interesting group of the identified biomolecules, regarding the possibility of learning about new properties and functions of royal jelly, are hypothetical and uncharacterized proteins. In this study, we detected 10 hypothetical proteins whose existence has been predicted based on the genetic information, but there is any experimental evidence proving their in vivo expression. The functions of these proteins, as in the case of uncharacterized proteins, have not been investigated yet. For these proteins, we performed BLAST analysis (https:/ /blast.ncbi.nlm.nih.gov/, accessed on 11 January 2021) to find similar regions in various biological sequences. This approach helps to assess functional relationships between proteins and identify members of protein families. Results of our analysis are presented in Table 2 .

Table 2. Results of BLAST analysis.

\begin{tabular}{|c|c|c|c|c|c|}
\hline Accession & Protein Name & Significant Alignment Sequence & $\begin{array}{l}\text { Query } \\
\text { Coverage }\end{array}$ & $\begin{array}{l}\text { Percent } \\
\text { Identity }\end{array}$ & E-Value \\
\hline gi | 110756431 & $\begin{array}{l}\text { Predicted: hypothetical protein } \\
\text { LOC725074 [Apis mellifera] }\end{array}$ & $\begin{array}{l}\text { omega-conotoxin-like protein } 1 \\
\text { [Apis mellifera] }\end{array}$ & $100 \%$ & $100.00 \%$ & $2.00 \times 10^{-47}$ \\
\hline gi | 110763647 & $\begin{array}{l}\text { Predicted: hypothetical protein } \\
\text { LOC726323 [Apis mellifera] }\end{array}$ & $\begin{array}{l}\text { uncharacterized protein LOC726323 } \\
\text { isoform X1 [Apis mellifera] }\end{array}$ & $100 \%$ & $99.39 \%$ & $1.00 \times 10^{-116}$ \\
\hline gi | 328777366 & $\begin{array}{l}\text { Predicted: hypothetical protein } \\
\text { LOC100577348 [Apis mellifera] }\end{array}$ & $\begin{array}{c}\text { uncharacterized protein } \\
\text { LOC100577348 isoform X2 } \\
\text { [Apis mellifera] }\end{array}$ & $98 \%$ & $98.37 \%$ & 0.0 \\
\hline gi | 328779534 & $\begin{array}{l}\text { Predicted: hypothetical protein } \\
\text { LOC552041 [Apis mellifera] }\end{array}$ & $\begin{array}{c}\text { uncharacterized protein } \\
\text { LOC102655185 isoform X1 } \\
\text { [Apis mellifera] }\end{array}$ & $100 \%$ & $71.55 \%$ & $5.00 \times 10^{-92}$ \\
\hline \multirow[t]{2}{*}{ gi | 328782858} & \multirow{2}{*}{$\begin{array}{l}\text { Predicted: hypothetical protein } \\
\text { LOC410515 [Apis mellifera] }\end{array}$} & $\begin{array}{c}\text { uncharacterized protein LOC410515 } \\
\text { [Apis mellifera] }\end{array}$ & $93 \%$ & $100.00 \%$ & 0.0 \\
\hline & & $\begin{array}{l}\text { chorion peroxidase } \\
\text { [Habropoda laboriosa] }\end{array}$ & $93 \%$ & $62.86 \%$ & 0.0 \\
\hline gi 328783362 & $\begin{array}{l}\text { Predicted: hypothetical protein } \\
\text { LOC725249 [Apis mellifera] }\end{array}$ & $\begin{array}{c}\text { chymotrypsin inhibitor-like } \\
\text { [Apis mellifera] }\end{array}$ & $84 \%$ & $100.00 \%$ & $1.00 \times 10^{-25}$ \\
\hline gi | 328783471 & $\begin{array}{l}\text { Predicted: hypothetical protein } \\
\text { LOC725114 isoform } 1 \text { [Apis mellifera] }\end{array}$ & chymotrypsin inhibitor [Apis mellifera] & $100 \%$ & $100.00 \%$ & $2.00 \times 10^{-59}$ \\
\hline \multirow[t]{2}{*}{ gi| 328784821} & \multirow{2}{*}{$\begin{array}{l}\text { Predicted: hypothetical protein } \\
\text { LOC100577210 [Apis mellifera] }\end{array}$} & $\begin{array}{c}\text { uncharacterized protein LOC413627 } \\
\text { [Apis mellifera] }\end{array}$ & $77 \%$ & $100.00 \%$ & $6.00 \times 10^{-45}$ \\
\hline & & regucalcin [Apis cerana cerana] & $77 \%$ & $94.81 \%$ & $4.00 \times 10^{-45}$ \\
\hline \multirow{3}{*}{ gi | 328792767} & \multirow{3}{*}{$\begin{array}{l}\text { Predicted: hypothetical protein } \\
\text { LOC724993 [Apis mellifera] }\end{array}$} & $\begin{array}{c}\text { uncharacterized protein LOC724993 } \\
\text { [Apis mellifera] }\end{array}$ & $83 \%$ & $90.37 \%$ & $0.00 \times 10^{+00}$ \\
\hline & & $\begin{array}{l}\text { Predicted: kielin/chordin-like protein } \\
\text { [Trachymyrmex zeteki] }\end{array}$ & $82 \%$ & $45.91 \%$ & $2.00 \times 10^{-85}$ \\
\hline & & $\begin{array}{l}\text { kielin/chordin-like protein } \\
\text { [Nasonia vitripennis] }\end{array}$ & $81 \%$ & $47.06 \%$ & $3.00 \times 10^{-89}$ \\
\hline gi | 380012917 & $\begin{array}{l}\text { Predicted: uncharacterized protein } \\
\text { LOC100870850 [Apis florea] }\end{array}$ & $\begin{array}{c}\text { uncharacterized protein LOC408608 } \\
\text { [Apis mellifera] }\end{array}$ & $99 \%$ & $73.33 \%$ & $2.00 \times 10^{-84}$ \\
\hline \multirow[t]{2}{*}{ gi | 380023404} & \multirow{2}{*}{$\begin{array}{l}\text { Predicted: uncharacterized protein } \\
\text { LOC100869599 [Apis florea] }\end{array}$} & $\begin{array}{l}\text { uncharacterized protein } \\
\text { LOC102654257 [Apis mellifera] }\end{array}$ & $100 \%$ & $94.71 \%$ & $7.00 \times 10^{-116}$ \\
\hline & & $\begin{array}{l}\text { low-density lipoprotein receptor } \\
\text { 1-like isoform X3 [Vespa mandarinia] }\end{array}$ & $98 \%$ & $55.88 \%$ & $7.00 \times 10^{-57}$ \\
\hline gi | 380026601 & $\begin{array}{l}\text { Predicted: uncharacterized protein } \\
\text { LOC100863702 [Apis florea] }\end{array}$ & ataxin-2 [Apis cerana cerana] & $77 \%$ & $88.41 \%$ & $5.00 \times 10^{-30}$ \\
\hline gi | 380027252 & $\begin{array}{l}\text { Predicted: uncharacterized protein } \\
\text { LOC100864410 [Apis florea] }\end{array}$ & odorant receptor Or1 [Apis mellifera] & $98 \%$ & $89.68 \%$ & 0.0 \\
\hline gi | 48094573 & $\begin{array}{l}\text { Predicted: hypothetical protein } \\
\text { LOC408608 [Apis mellifera] }\end{array}$ & $\begin{array}{c}\text { uncharacterized protein LOC408608 } \\
\text { [Apis mellifera] }\end{array}$ & $100 \%$ & $100.00 \%$ & $3.00 \times 10^{-124}$ \\
\hline
\end{tabular}

For the identified gi I 110756431 protein (Predicted: hypothetical protein LOC725074 [Apis mellifera]), we found a significant alignment sequence referred to omega-conotoxinlike protein 1 [Apis mellifera]. This protein was also found in bee venom in our previous studies, based on HPLC, nanoLC-MALDI-TOF/TOF MS/MS, and LC-ESI-QToF methodology [56,57]. With a high degree of probability, we can conclude that the molecule we have identified corresponds entirely to the results obtained from the BLAST platform, as both query coverage and per cent identity equal $100 \%$. It means that our identified 
sequence exactly corresponds to conotoxin-like protein 1 . As far as we know, this protein has never been reported to be included in RJ before. Detection of conotoxin-like protein 1 in royal jelly is a particularly important discovery in terms of the safety of RJ and also its potential therapeutic use. Conotoxins are small, disulfide-rich, neurotoxic peptides isolated from the marine cone snails venom. There are many types of these molecules, differing in structure and function [58]. The mechanism of their action has not been utterly elucidated yet. However, it is known that they bind to ion channels, neurotransmitters, transporters, and neural receptors [59]. Because of their selective binding to neuronal targets, conotoxins may be used for the developments of new drugs. Moreover, these peptides may be potentially used in the treatment of neurodegenerative conditions, like Alzheimer or Parkinson diseases [60]. Results of our study suggest that conotoxin may also affect the therapeutic effect of RJ, especially since some studies revealed that RJ shows a neuroprotective effect [61-63]. What is interesting, is that it has been investigated whether the consumption of RJ can be beneficial in the treatment of behavioral deficits in Alzheimer's disease in rabbits [64]. Thus, the presence of conotoxin-like protein 1 in RJ may contribute to elucidate the neuroprotective effect caused by RJ. Interestingly, Kaplan et al. [65] found this protein to be mainly expressed in the bee brain. It's also worth noting that expression of a protein with an approximate mass of $8.2 \mathrm{kDa}$, referred to as omega-conotoxin-like protein 1, has been reported by Gätschenberger et al. [66] to be induced in the haemolymph of young drones as a response to a septic injury. It may suggest that this protein participates in an immune response.

The next protein, for which the sequence similarity was noticed, was ataxin- 2 . This protein has been found in the BLAST analysis of gi I 380026601 (Predicted: uncharacterised protein LOC100863702 [Apis florea]). However, database searching returned the BLAST scores under $100 \%$ (77\% query coverage and $88.41 \%$ per cent identity). Therefore, the presence of this protein (or its homolog) in royal jelly should be confirmed in further research. Ataxin-2 is an RNA-binding protein, which regulates mRNA stability and translation. It participates in cell death, calcium homeostasis, and cellular metabolism $[67,68]$. In insects, ataxin-2 is involved in the regulation of circadian rhythms but also in the development of peripheral tissue [69-71]. This may explain the presence of ataxin-2 in RJ.

Other peptides that have been found to be similar to the sequences detected in RJ are odorant receptor Or1 and chymotrypsin inhibitor. These proteins play mainly regulatory functions. Odorant receptor Or1 targets in bee's periphery nervous system. It participates in the odorants transport and binding, and therefore, in the behavioral response to specific odorants [72]. Chymotrypsin inhibitor prevents proteolysis of proteins present in RJ. For the chymotrypsin inhibitor, 100\% similarity to gi I 328783471 (Predicted: hypothetical protein LOC725114 isoform 1 [Apis mellifera]) was found. However, query coverage was lower $(84 \%)$ for the analysis of gi I 328783362 (Predicted: hypothetical protein LOC725249 [Apis mellifera]). Regarding odorant receptor Or1, the similarity with Predicted: uncharacterised protein LOC100864410 [Apis florea] detected in our study was expressed with $98 \%$ query coverage and $89.68 \%$ per cent identity. Therefore, these proteomic features require further research.

Other peptides for which a partial similarity to the RJ-detected proteins was found were Chorion peroxidase, regucalcin, kielin/chordin-like protein, and low-density lipoprotein receptor 1-like isoform X3. All those proteins bear mainly regulatory functions. However, due to lower BLAST scores (see Table 2), a certain identification must be proved by additional analyses. For the remaining hypothetical and uncharacterized proteins found in royal jelly, no defined references were found in BLAST analysis. The structure, functions and properties of these proteins should be investigated in future research. However, gi I 380012917 (Predicted: uncharacterized protein LOC100870850 [Apis florea]), and gi | 48094573 (uncharacterized protein LOC408608 [Apis mellifera]) were found in Hymenoptera venom in our previous study [56].

As the number of fully sequenced honeybee proteins and peptides increases, omics and bioinformatics technologies provide a tremendous amount of information about se- 
quential biomolecules that function in various biological aspects of the honeybee and that are found in its products. In the postgenomic era, the international project i5K (http://i5k.github.io/.2018, accessed on 16 February 2021) not only played an important role in understanding the honeybee genome but also resulted in extensive research on the bee's proteome and the identification of many active proteins and peptides in its products. For a number of new substances produced by honeybee, only one type of biological activity has been identified, and their wider physiological role is unknown. Because many substances often exhibit pleiotropic biological activity, there is a need to understand a wider spectrum of biological activity for newly discovered compounds. It is also necessary to develop new, specific, and sensitive physiological, pharmacological, or toxicological bioassays. In the last decade, we have been observing new trends in the development of modern biotechnology, where besides medical, industrial, food and plant protection biotechnology, the term "Yellow Biotechnology" was introduced as an alternative term for insect biotechnology, opening new horizons for multidisciplinary research in the field of experimental entomology [73]. Yellow biotechnology is defined as the use of biotechnology to transform insects, their molecules, cells or organs into products and services with great potential for applications in biomedicine, pharmacy, and industry, where the honeybee may be one of the candidates.

\section{Materials and Methods}

\subsection{Royal Jelly}

In this study, we analyzed three samples of fresh RJ, collected in June 2019. The non-commercial apiary, from which all fresh samples were collected, is located in Góry Złotnickie village (51 $87^{\prime} 504^{\prime \prime}$ N, $18^{\circ} 12^{\prime} 431^{\prime \prime}$ E) in Poland (Greater Poland Voivodeship, west-central Poland). Right after the collection, samples were stored at $-80{ }^{\circ} \mathrm{C}$ until analyses. All RJ samples were analyzed in three technical replicates.

\subsection{Pre-Treatment of the Royal Jelly Samples}

Samples of fresh royal jelly were first suspended in ultrapure water in a concentration of $330 \mathrm{mg} / \mathrm{mL}$. The RJ-water suspensions were mixed with vortex for $1 \mathrm{~min}$ and then sonicated for $20 \mathrm{~min}$. After sonication, suspensions were vortex-mixed for $1 \mathrm{~min}$ and subsequently spun with 13,000 RPM (9600 RCF) for $20 \mathrm{~min}$. Collected supernatants (in this study called "extracts") were used in further steps.

\subsection{Relative Protein Enrichment-ProteoMiner ${ }^{T M}$ Hexapeptide Ligand Library}

For the presented research, we applied a commercial ProteoMiner ${ }^{\mathrm{TM}}$ Sequential Elution Small Capacity Kit (Bio-Rad, Hercules, CA, USA). All enrichment steps were performed strictly according to the manufacturer's instructions. The only difference from the manufacturer's protocol was the type of the sample solution loaded onto the ProteoMiner ${ }^{\mathrm{TM}}$ column. Instead of the $0.2 \mathrm{~mL}$ of serum (for which the protocol is optimized), we added $0.2 \mathrm{~mL}$ of RJ extract, prepared as described above (see Section 4.2). In brief, $0.2 \mathrm{~mL}$ of the $\mathrm{RJ}$ water extracts were loaded onto pre-conditioned ProteoMiner ${ }^{\mathrm{TM}}$ columns containing slurry beads and incubated at room temperature (RT) on a platform shaker. Next the samples were washed with phosphate buffer saline (PBS), and sequentially eluted with solvents: 1 M sodium chloride, 20 mM HEPES, pH 7.4 (Elution Reagent 1), $200 \mathrm{mM}$ glycine, pH 2.4 (Elution Reagent 2), 60\% ethylene glycol in water (Elution Reagent 3), and 33.3\% 2-propanol, 16.7\% acetonitrile (ACN), $0.1 \%$ trifluoroacetic acid (TFA) (Elution Reagent 4 ). In total, 4 separate fractions were obtained from each sample. These fractions were further trypsin digested and then purified with ZipTip.

\subsection{Trypsin Proteolytic Digestion and ZipTip Concentration and Purification}

All RJ fractions derived from the ProteoMiner ${ }^{\mathrm{TM}}$ enrichment method and additionally crude RJ solutions (water suspended and sonicated, but not fractionated with ProteoMiner ${ }^{\mathrm{TM}}$; three technical repetitions) were subjected to digestion with trypsin 
(Promega, Madison, WI, USA). We applied a modified protocol from pierce in-solution tryptic digestion kit. In brief, before adding trypsin, proteins in extracts (both ProteoMiner ${ }^{\mathrm{TM}}$ fractions and "crude" extracts non-enriched with ProteoMiner ${ }^{\mathrm{TM}}$ ) were denatured, reduced, and alkylated. Subsequently, after trypsin addition, RJ extracts were digested at $37^{\circ} \mathrm{C}$ overnight. In the next step, ZipTip C18 (Millipore, Bedford, MA, USA) reverse phase chromatography micropipette tips were used to purify, desalt and concentrate digested RJ protein extracts before mass spectrometry analyses. Tips were conditioned using ACN and $0.1 \% \mathrm{TFA} /$ water. Then, each solution of the digested proteins extracted from the RJ samples (the exact solutions formed due to trypsin digestion of the RJ extracts, without any additional reagents) was loaded onto ZipTip tips according to the manufacturer's instruction. Sample solutions were aspirated and dispensed in 10 cycles for maximum binding of proteins. After washing with $0.1 \%$ TFA, bound proteins and peptides were eluted with $50 \%$ ACN in $0.1 \%$ TFA.

\subsection{NanoLC-MALDI-TOF/TOF MS/MS Analyses}

For the identification of peptides and proteins included in RJ, the nanoLC-MALDITOF/TOF MS/MS technique was applied. Subsequent to ZipTip depletion, RJ protein extracts were subjected to nanoLC fractionation. The nanoLC set consisted of EASY-nLC II (Bruker Daltonics, Bremen, Germany) nanoflow HPLC system, and Proteineer-fc II (Bruker Daltonics, Bremen, Germany) collector of fractions. The nanoLC system parts were: NS-MP-10 BioSphere C18 (NanoSeparations, Nieuwkoop, the Netherlands) trap column $(20 \mathrm{~mm} \times 100 \mu \mathrm{m}$ I.D., particle size $5 \mu \mathrm{m}$, pore size $120 \AA$ ), and an Acclaim PepMap 100 (Thermo Scientific, Sunnyvale, CA, USA) column (150 mm $\times 75 \mu \mathrm{m}$ I.D., particle size $3 \mu \mathrm{m}$, pore size $100 \AA$ ). The gradient elution method was set on $2-50 \%$ of ACN in $96 \mathrm{~min}$ (mobile phase $\mathrm{A}-0.05 \%$ TFA in water, mobile phase $\mathrm{B}-0.05 \%$ TFA in $90 \% \mathrm{ACN}$ ). The flow rate for separation was $300 \mathrm{~nL} / \mathrm{min}$, and the volume of the sample eluent injected into the chromatography column was $4 \mu \mathrm{L}$. The nanoLC system was operated by HyStar 3.2 (Bruker Daltonics, Bremen, Germany) software. In total, 384 fractions were obtained in the nanoLC separation process. Fractions were mixed with a matrix solution consisted of $36 \mu \mathrm{L}$ of HCCA saturated solution in 0.1\% TFA and acetonitrile (90:10 v/v), $748 \mu \mathrm{L}$ of acetonitrile and $0.1 \%$ TFA $(95: 5 v / v)$ mixture, $8 \mu \mathrm{L}$ of $10 \%$ TFA, and $8 \mu \mathrm{L}$ of $100 \mathrm{mM}$ ammonium phosphate, and spotted automatically onto the AnchorChip 384 (Bruker Daltonics, Bremen, Germany) target plate by the collector of fractions. Fractions were subsequently subjected to MS/MS analysis. For this purpose, UltrafleXtreme (Bruker Daltonics, Bremen, Germany) mass spectrometer was used (mass range $m / z$ of $700-3500$, reflectron mode). External calibration was performed with a mixture of Peptide Calibration Standard (Bruker Daltonics, Bremen, Germany). The list of the precursor ions for the identification was established with WARP-LC (Bruker Daltonics, Bremen, Germany) software. For the spectra acquisition, processing and evaluation FlexControl 3.4, FlexAnalysis 3.4 and BioTools 3.2 (Bruker Daltonics, Bremen, Germany) software were used. For the identification of discriminative proteins and peptides, an NCBI database and Mascot 2.4.1 search engine with taxonomic restriction to Apis spp. were applied. The protein search parameters were as follows: fragment ion mass tolerance $m / z \pm 0.7$, precursor ion mass tolerance $\pm 50 \mathrm{ppm}$, peptide charge +1 , monoisotopic mass.

\section{Conclusions}

The functional and health-promoting properties of RJ make it one of the most attractive healthy ingredients. However, because of an overly complicated composition, RJ is not yet fully characterized and may cause adverse effects. Therefore, in this study, we proposed an advanced strategy based on combinatorial hexapeptide ligand libraries (ProteoMiner ${ }^{\mathrm{TM}}$ kit) for the proteomic analysis of RJ water extracts. We identified a total of 86 proteins taxonomically classified to Apis spp. (bees). In addition to the well-known components of RJ, we identified 10 hypothetical proteins and 4 uncharacterized proteins. We also proved the utility of the ProteoMiner ${ }^{\mathrm{TM}}$ technique in the analysis of complex biological 
samples, as 74 out of all identified proteins were detected in RJ extracts pre-treated with ProteoMiner $^{\mathrm{TM}}$ kit, and only 50 proteins were found in extracts that were not enriched with this technique. Broadening the knowledge of RJ composition may contribute to the development of standards and regulations, enhancing the quality of RJ, and consequently, the safety of its supplementation. Moreover, better characterization of proteins and peptides found in RJ may support the understanding of the functional properties of RJ regarding both humans and bees.

Author Contributions: Conceptualization, J.M. (Jan Matysiak) and G.R.; methodology, E.M. and J.M. (Jan Matysiak); software, E.M.; validation, E.M.; formal analysis, E.M. and J.M. (Joanna Matysiak); investigation, E.M.; resources, J.M. (Jan Matysiak); data curation, E.M.; Writing-Original draft preparation, E.M., J.M. (Joanna Matysiak), G.R., E.K., W.Z., J.Z. and J.M. (Jan Matysiak); WritingReview and Editing, E.M., J.M. (Joanna Matysiak), G.R. and J.M. (Jan Matysiak); visualization, E.M.; supervision, J.M. (Jan Matysiak); project administration, J.M. (Jan Matysiak); funding acquisition, J.M. (Jan Matysiak). All authors have read and agreed to the published version of the manuscript.

Funding: This project received financial support from the Polish National Science Centre (grant number 2016/23/D/NZ7/03949).

Data Availability Statement: The data presented in this study are contained within the article.

Conflicts of Interest: The authors declare no conflict of interest.

\section{References}

1. Denisow, B.; Denisow-Pietrzyk, M. Biological and therapeutic properties of bee pollen: A review. J. Sci. Food Agric. 2016, 96, 4303-4309. [CrossRef]

2. Fratini, F.; Cilia, G.; Mancini, S.; Felicioli, A. Royal Jelly: An ancient remedy with remarkable antibacterial properties. Microbiol. Res. 2016, 192, 130-141. [CrossRef]

3. Taulavuori, K.; Julkunen-Tiitto, R.; Hyöky, V.; Taulavuori, E. Blue Mood for Superfood. Nat. Prod. Commun. 2013, 8. [CrossRef]

4. Ramadan, M.F.; Al-Ghamdi, A. Bioactive compounds and health-promoting properties of royal jelly: A review. J. Funct. Foods 2012, 4, 39-52. [CrossRef]

5. Wytrychowski, M.; Chenavas, S.; Daniele, G.; Casabianca, H.; Batteau, M.; Guibert, S.; Brion, B. Physicochemical characterisation of French royal jelly: Comparison with commercial royal jellies and royal jellies produced through artificial bee-feeding. J. Food Compos. Anal. 2013, 29, 126-133. [CrossRef]

6. Sabatini, A.G. Quality and standardisation of Royal Jelly. J. ApiProd. ApiMed. Sci. 2009, 1, 16-21. [CrossRef]

7. Garcia-Amoedo, L.H.; De Almeida-Muradian, L.B. Physicochemical composition of pure and adulterated royal jelly. Quim. Nova 2007, 30, 257-259. [CrossRef]

8. Alvarez-Suarez, J.M. Bee Products-Chemical and Biological Properties; Springer International Publishing: New York, NY, USA, 2017; pp. 1-306.

9. Priomorac, L.; Bilić Rajs, B.; Puškadija, Z.; Kovačić, M.; Vukadin, I.; Flanjak, I. Physicochemical characteristics of Croatian royal jelly. Croat. J. Food Sci. Technol. 2019, 11, 266-271.

10. Balkanska, R.; Crenguta, P. Comparison of physicochemical parameters in royal jelly from Romania and Bulgaria. Bull. Univ. Agric. Sci. Vet. Med. Cluj-Napoca Anim. Sci. Biotechnol. 2013, 70, 117-121.

11. Scarselli, R.; Donadio, E.; Giuffrida, M.G.; Fortunato, D.; Conti, A.; Balestreri, E.; Felicioli, R.; Pinzauti, M.; Sabatini, A.G.; Felicioli, A. Towards royal jelly proteome. Proteomics 2005, 5, 769-776. [CrossRef]

12. Lercker, G.; Caboni, M.F.; Vecchi, M.A.; Sabatini, A.G.; Nanetti, A. Caratterizzazione dei principali costituenti della gelatina reale. Apicoltura 1992, 8, 27-37.

13. Sano, O.; Kunikata, T.; Kohno, K.; Iwaki, K.; Ikeda, M.; Kurimoto, M. Characterization of Royal Jelly Proteins in both Africanized and European Honeybees (Apis mellifera) by Two-Dimensional Gel Electrophoresis. J. Agric. Food Chem. 2004, 52, 15-20. [CrossRef]

14. Buttstedt, A.; Moritz, R.F.A.; Erler, S. Origin and function of the major royal jelly proteins of the honeybee (Apis mellifera) as members of the yellow gene family. Biol. Rev. 2014, 89, 255-269. [CrossRef] [PubMed]

15. Kamakura, M. Royalactin induces queen differentiation in honeybees. Nature 2011, 473, 478-483. [CrossRef]

16. Buttstedt, A.; Ihling, C.H.; Pietzsch, M.; Moritz, R.F.A. Royalactin is not a royal making of a queen. Nature 2016, 537, E10-E12. [CrossRef]

17. Fujita, T.; Kozuka-Hata, H.; Ao-Kondo, H.; Kunieda, T.; Oyama, M.; Kubo, T. Proteomic Analysis of the Royal Jelly and Characterization of the Functions of its Derivation Glands in the Honeybee. J. Proteome Res. 2013, 12, 404-411. [CrossRef] [PubMed]

18. Schönleben, S.; Sickmann, A.; Mueller, M.J.; Reinders, J. Proteome analysis of Apis mellifera royal jelly. Anal. Bioanal. Chem. 2007, 389, 1087-1093. [CrossRef] [PubMed] 
19. Han, B.; Li, C.; Zhang, L.; Fang, Y.; Feng, M.; Li, J. Novel royal jelly proteins identified by gel-based and gel-free proteomics. J. Agric. Food Chem. 2011, 59, 10346-10355. [CrossRef] [PubMed]

20. Furusawa, T.; Rakwal, R.; Nam, H.W.; Shibato, J.; Agrawal, G.K.; Kim, Y.S.; Ogawa, Y.; Yoshida, Y.; Kouzuma, Y.; Masuo, Y.; et al. Comprehensive royal jelly (RJ) proteomics using one- and two-dimensional proteomics platforms reveals novel RJ proteins and potential phospho/glycoproteins. J. Proteome Res. 2008, 7, 3194-3229. [CrossRef] [PubMed]

21. Li, J.; Wang, T.; Zhang, Z.; Pan, Y. Proteomic analysis of royal jelly from three strains of western honeybees (Apis mellifera). J. Agric. Food Chem. 2007, 55, 8411-8422. [CrossRef]

22. Hu, F.L.; Bíliková, K.; Casabianca, H.; Daniele, G.; Salmen Espindola, F.; Feng, M.; Guan, C.; Han, B.; Krištof Kraková, T.; Li, J.K.; et al. Standard methods for Apis mellifera royal jelly research. J. Apic. Res. 2017, 58, 1-68. [CrossRef]

23. Collazo, N.; Carpena, M.; Nuñez-Estevez, B.; Otero, P.; Simal-Gandara, J.; Prieto, M.A. Health Promoting Properties of Bee Royal Jelly: Food of the Queens. Nutrients 2021, 13, 543. [CrossRef] [PubMed]

24. Zhang, L.; Han, B.; Li, R.; Lu, X.; Nie, A.; Guo, L.; Fang, Y.; Feng, M.; Li, J. Comprehensive identification of novel proteins and N-glycosylation sites in royal jelly. BMC Genom. 2014, 15, 135. [CrossRef] [PubMed]

25. Zhang, L.; Fang, Y.; Li, R.; Feng, M.; Han, B.; Zhou, T.; Li, J. Towards posttranslational modification proteome of royal jelly. J. Proteom. 2012, 75, 5327-5341. [CrossRef] [PubMed]

26. Han, B.; Fang, Y.; Feng, M.; Lu, X.; Huo, X.; Meng, L.; Wu, B.; Li, J. In-depth phosphoproteomic analysis of royal jelly derived from western and eastern honeybee species. J. Proteome Res. 2014, 13, 5928-5943. [CrossRef] [PubMed]

27. Greco, V.; Piras, C.; Pieroni, L.; Ronci, M.; Putignani, L.; Roncada, P.; Urbani, A. Applications of MALDI-TOF mass spectrometry in clinical proteomics. Expert Rev. Proteom. 2018, 15, 683-696. [CrossRef]

28. Hajduk, J.; Matysiak, J.; Kokot, Z.J. Challenges in biomarker discovery with MALDI-TOF MS. Clin. Chim. Acta 2016, 458, 84-98. [CrossRef]

29. Li, S.; He, Y.; Lin, Z.; Xu, S.; Zhou, R.; Liang, F.; Wang, J.; Yang, H.; Liu, S.; Ren, Y. Digging More Missing Proteins Using an Enrichment Approach with ProteoMiner. J. Proteome Res. 2017, 16, 4330-4339. [CrossRef]

30. Righetti, P.G.; Boschetti, E.; Lomas, L.; Citterio, A. Protein Equalizer ${ }^{\mathrm{TM}}$ Technology: The quest for a "democratic proteome". Proteomics 2006, 6, 3980-3992. [CrossRef]

31. Boschetti, E.; Righetti, P.G. The ProteoMinerin the proteomic arena: A non-depleting tool for discovering low-abundance species. J. Proteom. 2008, 71, 255-264. [CrossRef]

32. Drapeau, M.D.; Albert, S.; Kucharski, R.; Prusko, C.; Maleszka, R. Evolution of the Yellow/Major Royal Jelly Protein family and the emergence of social behavior in honey bees. Genome. Res. 2006, 16, 1385-1394. [CrossRef]

33. Santos, K.S.; Delazari dos Santos, L.; Mendes, M.; Monson de Souza, B.; Malaspina, O.; Palma, M.S. Profiling the proteome complement of the secretion from hypopharyngeal gland of Africanized nurse-honeybees (Apis mellifera L.). Insect Biochem. Mol. Biol. 2005, 35, 85-91. [CrossRef]

34. Schmitzová, J.; Klaudiny, J.; Albert, Š.; Schröder, W.; Schreckengost, W.; Hanes, J.; Júdová, J.; Šimúth, J. A family of major royal jelly proteins of the honeybee Apis mellifera L. Cell. Mol. Life Sci. 1998, 54, 1020-1030. [CrossRef]

35. Hanes, J.; Šimuth, J. Identification and partial characterisation of the major royal jelly protein of the honey bee (Apis mellifera L.). J. Apic. Res. 1992, 31, 22-26. [CrossRef]

36. Ramanathan, A.N.K.G.; Nair, A.J.; Sugunan, V.S. A review on Royal Jelly proteins and peptides. J. Funct. Foods 2018, 44, 255-264. [CrossRef]

37. Buttstedt, A.; Mureşan, C.I.; Lilie, H.; Hause, G.; Ihling, C.H.; Schulze, S.H.; Pietzsch, M.; Moritz, R.F.A. How Honeybees Defy Gravity with Royal Jelly to Raise Queens. Curr. Biol. 2018, 28, 1095-1100.e3. [CrossRef]

38. Pirk, C.W.W. Honeybee Evolution: Royal Jelly Proteins Help Queen Larvae to Stay on Top. Curr. Biol. 2018, 28 , R350-R351. [CrossRef] [PubMed]

39. Mureşan, C.I.; Buttstedt, A. pH-dependent stability of honey bee (Apis mellifera) major royal jelly proteins. Sci. Rep. 2019, 9, 3-8. [CrossRef]

40. Ragland, S.A.; Criss, A.K. From bacterial killing to immune modulation: Recent insights into the functions of lysozyme. PLoS Pathog. 2017, 13, e1006512. [CrossRef]

41. Oliver, W.T.; Wells, J.E. Lysozyme as an alternative to growth promoting antibiotics in swine production. J. Anim. Sci. Biotechnol. 2015, 6, 35. [CrossRef]

42. McCleskey, C.S.; Melampy, R.M. Bactericidal Properties of Royal Jelly of the Honeybee. J. Econ. Entomol. 1939, 32, 581-587. [CrossRef]

43. Bílikova, K.; Huang, S.-C.; Lin, I.-P.; Šimuth, J.; Peng, C.-C. Structure and antimicrobial activity relationship of royalisin, an antimicrobial peptide from royal jelly of Apis mellifera. Peptides 2015, 68, 190-196. [CrossRef] [PubMed]

44. Shen, L.; Liu, D.; Li, M.; Jin, F.; Din, M.; Parnell, L.D.; Lai, C.-Q. Mechanism of Action of Recombinant Acc-Royalisin from Royal Jelly of Asian Honeybee against Gram-Positive Bacteria. PLoS ONE 2012, 7, e47194. [CrossRef] [PubMed]

45. Yang, Y.C.; Chou, W.M.; Widowati, D.A.; Lin, I.P.; Peng, C.C. 10-Hydroxy-2-Decenoic Acid of Royal Jelly Exhibits Bactericide and Anti-Inflammatory Activity in Human Colon Cancer Cells. BMC Complement. Altern. Med. 2018, 18, 202. [CrossRef] [PubMed]

46. Kurek-Górecka, A.; Górecki, M.; Rzepecka-Stojko, A.; Balwierz, R.; Stojko, J. Bee Products in Dermatology and Skin Care. Molecules 2020, 25, 556. [CrossRef] 
47. Pavel, C.I.; Mărghitaş, L.A.; Bobiş, O.; Dezmirean, D.S.; Şapcaliu, A.; Radoi, I.; Mădaş, M.N. Biological Activities of Royal Jelly-Review. Sci. Pap. Anim. Sci. Biotechnol. 2011, 44, 108-118.

48. Spillner, E.; Blank, S.; Jakob, T. Hymenoptera Allergens: From Venom to "Venome". Front. Immunol. 2014, 5, 77. [CrossRef]

49. Tomsitz, D.; Brockow, K. Component Resolved Diagnosis in Hymenoptera Anaphylaxis. Curr. Allergy Asthma Rep. $2017,17,38$. [CrossRef] [PubMed]

50. Hoffman, D.R. Hymenoptera venom allergens. Clin. Rev. Allergy Immunol. 2006, 30, 109-128. [CrossRef]

51. Takahama, H.; Shimazu, T. Food-induced anaphylaxis caused by ingestion of royal jelly. J. Dermatol. 2006, 33, 424-426. [CrossRef]

52. Katayama, M.; Aoki, M.; Kawana, S. Case of anaphylaxis caused by ingestion of royal jelly. J. Dermatol. 2008, 35, 222-224. [CrossRef]

53. Mizutani, Y.; Shibuya, Y.; Takahashi, T.; Tsunoda, T.; Moriyama, T.; Seishima, M. Major royal jelly protein 3 as a possible allergen in royal jelly-induced anaphylaxis. J. Dermatol. 2011, 38, 1079-1081. [CrossRef] [PubMed]

54. Leung, R.; Lam, C.W.K.; Ho, A.; Chan, J.K.W.; Choy, D.; Lai, C.K.W. Allergic sensitisation to common environmental allergens in adult asthmatics in Hong Kong. Hong Kong Med. J. 1997, 3, 211-217.

55. Hata, T.; Furusawa-Horie, T.; Arai, Y.; Takahashi, T.; Seishima, M.; Ichihara, K. Studies of royal jelly and associated cross-reactive allergens in atopic dermatitis patients. PLOS ONE 2020, 15, e0233707. [CrossRef] [PubMed]

56. Matysiak, J.; Hajduk, J.; Światły, A.; Naskret, N.; Kokot, Z.J. Proteomic analysis of Apis mellifera venom determined by liquid chromatography (LC) coupled with nano-LC-MALDI-TOF/TOF MS. Acta. Pol. Pharm. Drug Res. 2017, 74, 53-65.

57. Matysiak, J.; Hajduk, J.; Mayer, F.; Hebeler, R.; Kokot, Z.J. Hyphenated LC-MALDI-ToF/ToF and LC-ESI-QToF approach in proteomic characterisation of honeybee venom. J. Pharm. Biomed. Anal. 2016, 121, 69-76. [CrossRef] [PubMed]

58. Robinson, S.D.; Norton, R.S. Conotoxin gene superfamilies. Mar. Drugs 2014, 12, 6058-6101. [CrossRef]

59. Daly, N.; Craik, D. Structural Studies of Conotoxins. IUBMB Life 2009, 61, 144-150. [CrossRef]

60. Dao, F.-Y.; Yang, H.; Su, Z.-D.; Yang, W.; Wu, Y.; Hui, D.; Chen, W.; Tang, H.; Lin, H. Recent Advances in Conotoxin Classification by Using Machine Learning Methods. Molecules 2017, 22, 1057. [CrossRef] [PubMed]

61. Ahmad, S.; Campos, M.G.; Fratini, F.; Altaye, S.Z.; Li, J. New insights into the biological and pharmaceutical properties of royal jelly. Int. J. Mol. Sci. 2020, 21, 382. [CrossRef]

62. Minami, A.; Matsushita, H.; Ieno, D.; Matsuda, Y.; Horii, Y.; Ishii, A.; Takahashi, T.; Kanazawa, H.; Wakatsuki, A.; Suzuki, T. Improvement of neurological disorders in postmenopausal model rats by administration of royal jelly. Climacteric 2016, 19, 568-573. [CrossRef]

63. Mohamed, A.A.-R.; Galal, A.A.A.; Elewa, Y.H.A. Comparative protective effects of royal jelly and cod liver oil against neurotoxic impact of tartrazine on male rat pups brain. Acta Histochem. 2015, 117, 649-658. [CrossRef]

64. Pan, Y.; Xu, J.; Jin, P.; Yang, Q.; Zhu, K.; You, M.; Hu, F.; Chen, M. Royal Jelly Ameliorates Behavioral Deficits, Cholinergic System Deficiency, and Autonomic Nervous Dysfunction in Ovariectomized Cholesterol-Fed Rabbits. Molecules 2019, 24, 1149. [CrossRef]

65. Kaplan, N.; Morpurgo, N.; Linial, M. Novel Families of Toxin-like Peptides in Insects and Mammals: A Computational Approach. J. Mol. Biol. 2007, 369, 553-566. [CrossRef] [PubMed]

66. Gätschenberger, H.; Gimple, O.; Tautz, J.; Beier, H. Honey bee drones maintain humoral immune competence throughout all life stages in the absence of vitellogenin production. J. Exp. Biol. 2012, 215, 1313-1322. [CrossRef] [PubMed]

67. Ostrowski, L.A.; Hall, A.C.; Mekhail, K. Ataxin-2: From RNA Control to Human Health and Disease. Genes 2017, 8, 157. [CrossRef] [PubMed]

68. Carmo-Silva, S.; Nobrega, C.; Pereira de Almeida, L.; Cavadas, C. Unraveling the Role of Ataxin-2 in Metabolism. Trends Endocrinol. Metab. 2017, 28, 309-318. [CrossRef]

69. Zhang, Y.; Ling, J.; Yuan, C.; Dubruille, R.; Emery, P. A role for Drosophila ATX2 in activation of PER translation and circadian behavior. Science 2013, 340, 879-882. [CrossRef]

70. Lim, C.; Allada, R. ATAXIN-2 Activates PERIOD Translation to Sustain Circadian Rhythms in Drosophila. Science 2013, 340, 875-879. [CrossRef]

71. Vianna, M.C.B.; Poleto, D.C.; Gomes, P.F.; Valente, V.; Paçó-Larson, M.L. Drosophila ataxin-2 gene encodes two differentially expressed isoforms and its function in larval fat body is crucial for development of peripheral tissues. FEBS OpenBio 2016, 6, 1040-1453. [CrossRef]

72. Venthur, H.; Zhou, J.-J. Odorant Receptors and Odorant-Binding Proteins as Insect Pest Control Targets: A Comparative Analysis. Front. Physiol. 2018, 9, 1163. [CrossRef] [PubMed]

73. Vilcinskas, A. Biotechnology I Insect Biotechnologie in Drug Discovery, 1st ed.; Vilcinskas, A., Ed.; Springer: Berlin/Heidelberg, Germany, 2013; p. 201. 